\title{
Assessment of Empirical Methods for Runoff Estimation in Chaskaman Catchment of Western Maharashtra, India
}

\author{
Pradip Dalavi $^{1 *}$, S.R. Bhakar ${ }^{1}$, H.N. Bhange ${ }^{2}$ and B.K. Gavit ${ }^{3}$ \\ ${ }^{1}$ Department of Soil and Water Engineering, CTAE, MPUAT, Udaipur, India \\ ${ }^{2}$ Department of Soil and Water Conservation Engineering, Dr. BSKKV, Dapoli, India \\ ${ }^{3}$ Department of Soil and Water Conservation Engineering, MPKV, Rahuri, India \\ *Corresponding author
}

\section{A B S T R A C T}

\section{Keywords}

Catchment, Empirical method, Precipitation, Runoff estimation,

Statistical performance

Article Info

Accepted:

12 April 2018

Available Online:

10 May 2018
In water resource management the main basic requirement is the estimation of runoff resulted from precipitation. In present study, runoff from Chaskaman catchment estimated using different empirical methods such as Inglis and DeSouza formula, Khosla's formula, Coutagine relationship, Department of irrigation India, and Strange's table method. Hydrological data such as observed daily runoff of 15 years (2000-2014) was collected from Superintending Engineer, Department of Irrigation, Government of Maharashtra, Pune. Performances of the empirical methods were evaluated using various statistical performance evaluation indices. From the result of the study, it is concluded that, the Coutagine relationship is the best method for estimation of runoff in Chaskaman catchment. In this study, from the results of the statistical performance evaluation Inglis and Desouza method indicated as the second best method after Coutagine relationship, for runoff estimation in the catchment area. Department of irrigation India and Strange's table method shows slightly high runoff as compared to all other methods.

\section{Introduction}

The estimation of runoff resulted from precipitation is prime important in planning and designing of water resources. Many researchers conducted research to estimate the surface runoff using various empirical equations. Surface runoff quantification is one of the most important factors in hydrologic problems analysis and water resources management. In India all watershed cannot be gauged therefore; indirect method of runoff quantification is needed. In this study, various empirical methods of runoff estimation are considered to estimate the runoff from catchment area of Chaskaman reservoir. The estimated results were compared with the observed data.

\section{Materials and Methods}

\section{Study area and data collection}

Chaskaman irrigation project is located across Bhima River, near village Bibi, Khedtahsil of Pune district in Maharashtra state. The Bhima River situated in Western Maharashtra and is a tributary of Krishna River. The catchment area 
of Bhima River up to the dam site is about 300.82 sq. $\mathrm{km}$. The geographical extent of the project is between $73^{\circ} 46^{\prime} 50^{\prime \prime} \mathrm{E}$ to $74^{\circ} 30^{\prime} 15^{\prime \prime}$ E longitude and $18^{\circ} 33^{\prime} 28^{\prime \prime} \mathrm{N}$ to $18^{\circ} 58^{\prime} 09^{\prime \prime} \mathrm{N}$ latitude. The precipitation data of 15 years (2000-2014) taken from the India Metrological Department Pune. Hydrological data such as observed daily Runoff was collected from Superintending Engineer, Department of Irrigation, Government of Maharashtra, Pune

\section{Estimation of runoff yield using different empirical methods and Strange's table}

In this study various empirical equations such as Inglis and DeSouza, Khosla's Formula, Coutagine relationship, Department of irrigation, India and Strange's table method were used for estimation of runoff from Chaskaman catchment. These empirical equations are described as follows:

\section{Inglis and DeSouza formula}

Inglis and DeSouza (1929) evolved two regional formulae between annual runoff $R$ and annual rainfall $\mathrm{P}$ in $\mathrm{cm}$ as follows (Subramanya, 2008):

For Deccan plateau

$R=\left(\frac{1}{254} P\right) *(P-17.8)$

For Ghat regions of western India

$R=0.85 P-30.5(2)$

\section{Khosla's Formula}

In this method, the amount of monthly runoff is calculated by following formula (Subramanya, 2008):

$R_{m}=P_{m}-L_{m}(3)$
$L_{m}=0.48 T_{m}(4)$

Where,

$\mathrm{R}_{\mathrm{m}}$ is monthly runoff of watershed in $\mathrm{cm}$,

$\mathrm{P}_{\mathrm{m}}$ is monthly precipitation in $\mathrm{cm}$ and $\mathrm{T}_{\mathrm{m}}$ is mean monthly temperature in ${ }^{\circ} \mathrm{C}$.

\section{Coutagine relationship}

Coutagine also after doing many studies on various watersheds, presented a general relationship as below (Alizade, 2009):

$$
\begin{aligned}
& D=P-\lambda \times P^{2}(5) \\
& \lambda=\frac{1}{0.8+0.14 \times T}(6) \\
& R=P-D(7)
\end{aligned}
$$

Where,

$\mathrm{P}$ is annual precipitation by $\mathrm{m}$,

$\mathrm{T}$ is mean temperature by ${ }^{\circ} \mathrm{C}$,

$\mathrm{R}$ is annual runoff by $\mathrm{m}$ and

$D$ is annual flow shortage. Coutagine relationship is applicable if, $\frac{1}{2 \lambda}<P<\frac{1}{8 \lambda}$

\section{Department of irrigation, India}

Management of Reihand plan presented the following relationship between the amount of annual precipitation and runoff of Reihand River (Gupta, 1992):

$$
R=P-1.17 \times P^{0.86}(8)
$$

Where, $\mathrm{P}$ is annual precipitation in $\mathrm{cm}$ and, $\mathrm{R}$ is annual runoff in $\mathrm{cm}$. 


\section{Strange's table method}

One of the widely used empirical methods for computation of runoff yield is the one developed by Strange. He developed a set of curves for the catchments. In these curves the runoff is read as percentage of rainfall. According to the yielding qualities, he classified the catchments as good, bad and average. For a certain rainfall, if the catchment yields a copious runoff, it is classified as good. If the yield is poor, it is classified as bad. All those catchments lying between these two types are classified as average catchments. Method for estimating the runoff volume in season is given (Subramanya, 2008). The correlation equation of best fitting lines relating percentage yield ratio $\left(\mathrm{Y}_{\mathrm{r}}\right)$ to precipitation $(\mathrm{P})$ could be expressed as,

\section{Results and Discussion}

Many empirical methods and relationships have been developed using analysis of limited data and the regional characteristics. Many researchers given their outcome as some relationships between precipitation and annual surface runoff. In this study following empirical methods and relationships including Inglis and DeSouza method, Khosla's method, Coutagine relationship, Department of irrigation, India and Strange's table method has been used to estimate the runoff for the Chaskaman catchment using the rainfall data of 15 years (2000-2014) taken from the India Metrological Department Pune. Using empirical methods and Strange's table method, 15 years of rainfall data were analyzed.

\section{Strange's table method}

\begin{tabular}{|c|c|c|c|}
\hline \multicolumn{2}{|l|}{ For Good catchment: } & \multirow[b]{2}{*}{$r^{2}=0.9994$} & \multirow[b]{2}{*}{$\ldots(9 a)$} \\
\hline For $\mathrm{P}<250 \mathrm{~mm}$, & $Y_{r}=7 \times 10^{-5} P^{2}-0.0003 P$ & & \\
\hline For $250<P<760$ mm, & $Y_{r}=0.0438 P-7.1671$ & $r^{2}=0.9997$ & $\ldots(9 b)$ \\
\hline For $760<P<1500 \mathrm{~mm}$, & $Y_{r}=0.0443 P-7.479$ & $r^{2}=1.0$ & $\ldots(9 \mathrm{c})$ \\
\hline \multicolumn{2}{|c|}{ For Average catchment: } & & \\
\hline For $\mathrm{P}<250 \mathrm{~mm}$ & $Y_{r}=6 \times 10^{-5} P^{2}-0.0022 P+0.1183$ & $r^{2}=0.9989$ & $\ldots(10 a)$ \\
\hline For $250<P<760$ mm, & $Y_{r}=0.0328 P-5.3933$ & $r^{2}=0.9997$ & $\ldots(10 b)$ \\
\hline For $760<\mathrm{P}<1500 \mathrm{~mm}$, & $Y_{r}=0.0333 P-5.7101$ & $r^{2}=0.9999$ & $\ldots(10 c)$ \\
\hline \multicolumn{2}{|l|}{ For Bad catchment: } & & \\
\hline For $P<250$ mm, & $Y_{r}=4 \times 10^{-5} P^{2}-0.0011 P+0.0567$ & $r^{2}=0.9985$ & $\ldots(11 \mathrm{a})$ \\
\hline For $250<P<760 \mathrm{~mm}$ & $Y_{r}=0.0219 P-3.5918$ & $r^{2}=0.9997$ & $\ldots(11 b)$ \\
\hline For $760<P<1500 \mathrm{~mm}$ & $Y_{r}=0.0221-3.771$ & $r^{2}=0.9997$ & $\ldots(11 \mathrm{c})$ \\
\hline
\end{tabular}

Where, $\mathrm{Y}_{\mathrm{r}}=$ Percentage yield ratio $=$ ratio of runoff to rainfall in percentage and $\mathrm{P}=$ Rainfall in $\mathrm{mm}$. 
Table.1 The results of statistical methods used for empirical models in Chaskaman catchment

\begin{tabular}{|l|l|l|l|l|l|}
\hline Methods & \multicolumn{1}{|c|}{$\begin{array}{c}\text { Inglis and } \\
\text { DeSouza } \\
\text { formula }\end{array}$} & $\begin{array}{c}\text { Khosla's } \\
\text { formula }\end{array}$ & $\begin{array}{c}\text { Coutagine } \\
\text { relationship }\end{array}$ & $\begin{array}{c}\text { Department of } \\
\text { irrigation, } \\
\text { India }\end{array}$ & $\begin{array}{c}\text { Strange's } \\
\text { table } \\
\text { method }\end{array}$ \\
\hline RMSE & 101.61 & 101.68 & 87.41 & 103.15 & 167.9 \\
\hline ISE & 22.34 & 22.18 & 17.85 & 24.02 & 55.12 \\
\hline MRE & 0.06 & 0.06 & 0.05 & 0.06 & 0.07 \\
\hline MBE & 70.4 & 74.36 & 36.2 & 51.09 & 119.66 \\
\hline NSE & 0.93 & 0.94 & 0.95 & 0.89 & 0.83 \\
\hline IA(D) & 0.89 & 0.82 & 0.91 & 0.78 & 0.79 \\
\hline r & 0.84 & 0.80 & 0.81 & 0.69 & 0.79 \\
\hline
\end{tabular}

Table.2 Ultimate results of ranking various empirical runoff estimation methods in Chaskaman catchment

\begin{tabular}{|l|l|l|l|l|l|}
\hline Methods & $\begin{array}{c}\text { Inglis and } \\
\text { DeSouza } \\
\text { formula }\end{array}$ & $\begin{array}{c}\text { Khosla's } \\
\text { formula }\end{array}$ & $\begin{array}{c}\text { Coutagine } \\
\text { relationship }\end{array}$ & $\begin{array}{l}\text { Department of } \\
\text { irrigation, } \\
\text { India }\end{array}$ & $\begin{array}{c}\text { Strange's } \\
\text { table } \\
\text { method }\end{array}$ \\
\hline RMSE & 2 & 3 & 1 & 4 & 5 \\
\hline ISE & 3 & 2 & 1 & 4 & 5 \\
\hline MRE & 3 & 2 & 1 & 4 & 5 \\
\hline MBE & 2 & 3 & 1 & 4 & 5 \\
\hline NSE & 3 & 2 & 1 & 4 & 5 \\
\hline IA(D) & 2 & 3 & 1 & 5 & 4 \\
\hline r & 1 & 3 & 2 & 5 & 4 \\
\hline Overall & 2 & 3 & 1 & 4 & 5
\end{tabular}

Fig.1 Variation between observed and estimated runoff by various empirical methods

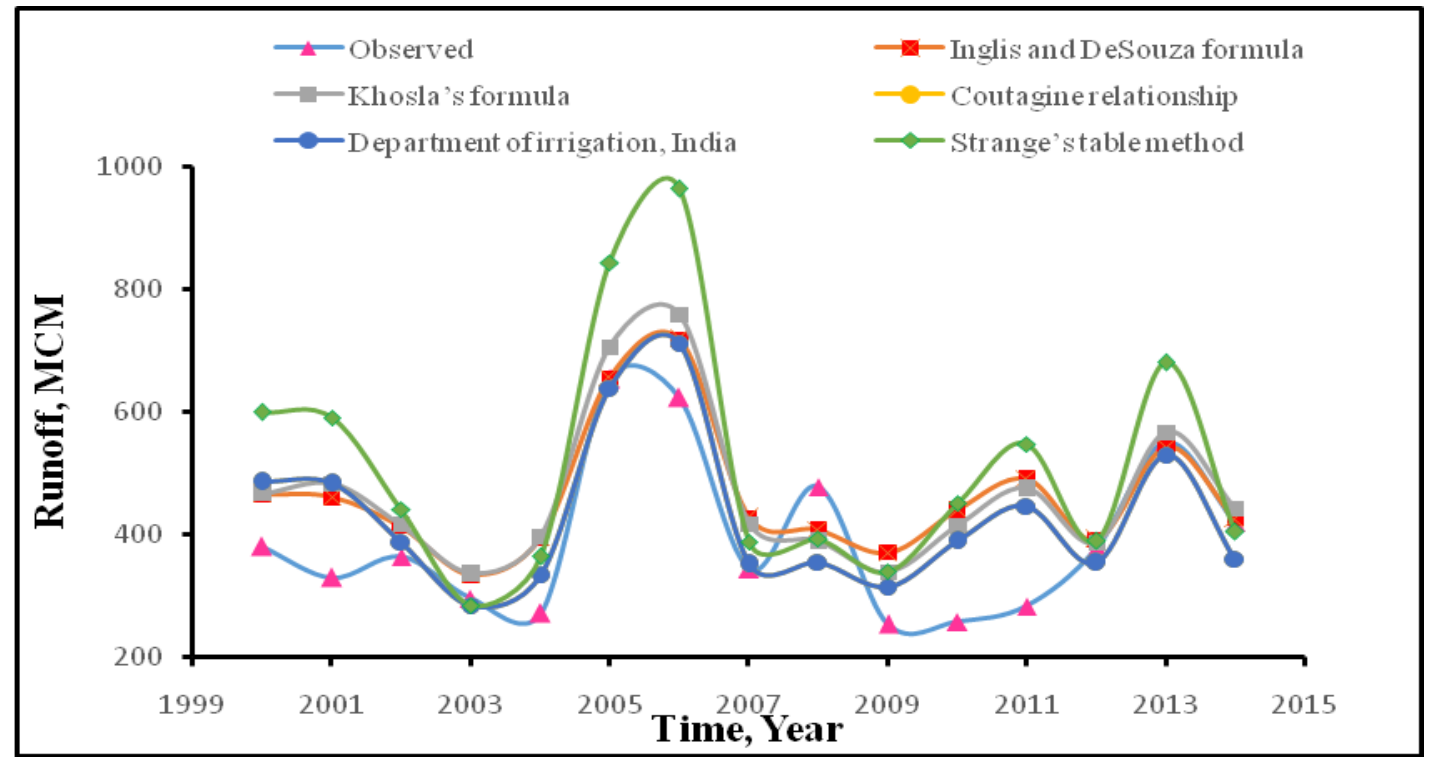


The runoff estimated by various empirical methods was compared with the observed values of runoff. The outcome obtained from statistical analysis methods used in this study have been presented for all tested empirical models in the Table 1. The results indicated that, the runoff yield results obtained from Inglis and DeSouza method, Khosla's method and Coutagine relationship are relatively closer to the observed runoff whereas, the result obtained by Department of irrigation, India and Strange's Table method are slightly higher than the observed one. Ultimate results of various empirical estimation methods ranking for Chaskaman catchment are presented in Table 2. The best model is the one with lowest amount of RMSE, ISE, MRE, MBE and optimum NSE, IA(D) and r. The variation between observed and estimated runoff graphically presented in Figure 1.

In this study, five runoff estimation equations were evaluated in Chaskaman catchment. Also, these equations were evaluated using observed and measured data in the catchment. The main aim of this study is to determine the most suitable equation for runoff estimation in Chaskaman catchment with minimum data requirement. From the results of the study it was revealed that, Coutagine relationship is the best method for estimation of runoff in Chaskaman catchment has the most efficiency and accuracy. Also, from the results of statistical tests Inglis and DeSouza formula indicated as the second best method after
Coutagine relationship, for runoff estimation in the Chaskaman catchment area.

\section{References}

Alizade, A. 1989. Principle of Applied Hydrology. Mashhad, Ghods Boniad Press. Pp.860-861.

Khopade, D.K. and Oak, P.R.A. 2014. Estimation of runoff yield for Nira Deogharcatchment using different empirical equations. The International Journal of Engineering and Science. 3(1): 75-81.

Khosravi, K., Mirzai, H. and Saleh, I. 2013. Assessment of Empirical Methods of Runoff Estimation by Statistical test (Case study: Banadak Sadat Watershed, Yazd Province). International Journal of Advanced Biological and Biomedical Research. 1(3): 285-301.

Latha, M. and Rajendran, M. 2015. An empirical Approach to Estimate Runoff of an Ungauged Catchment-Strange Table Method. International Journal of Research in Advent Technology.3(9): 125-128.

Praveen Kumar, B. J., Pradeep, H., Lokesh, A., Akarshraj, K. H., Surendra, H. J. and Avinash S. D. 2016. Estimation of Runoff using Empirical Equations and Fuzzy Logic method: A case study. International Journal of Scientific \& Engineering Research. 7(5): 28-36.

\section{How to cite this article:}

Pradip Dalavi, S.R. Bhakar, H.N. Bhange and Gavit, B.K. 2018. Assessment of Empirical Methods for Runoff Estimation in Chaskaman Catchment of Western Maharashtra. Int.J.Curr.Microbiol.App.Sci. 7(05): 1511-1515. doi: https://doi.org/10.20546/ijcmas.2018.705.177 